\title{
Insulinlike Growth Factor I Regulation of Growth Hormone Gene Transcription in Primary Rat Pituitary Cells
}

\author{
Shunichi Yamashita and Shlomo Melmed \\ Department of Medicine, Cedars-Sinai Medical Center, University of California, Los Angeles \\ School of Medicine, Los Angeles, California 90048
}

\begin{abstract}
We have previously shown that insulinlike growth factor I (IGF-I) inhibits growth hormone (GH) secretion and messenger RNA (mRNA) levels in pituitary cells. The effects of IGF-I on new GH mRNA synthesis rates in primary monolayer rat pituitary cells were therefore examined by nuclear runoff transcription assays. IGF-I (1.3 nM) treatment for $1 \mathrm{~h}$ inhibited GH gene transcription to $60 \%$ of controls. IGF-I (3.25 $\mathrm{nM}$ ) maximally suppressed GH gene transcription to $30 \%$ of control values after $4 \mathrm{~h}$. After $24 \mathrm{~h}$ treatment, GH transcription was suppressed to $48 \%$ of controls by $3.25 \mathrm{nM}$ IGF-I. IGF-I (3.25 $\mathrm{nM})$ also inhibited the twofold growth hormone-releasing hormone (GHRH) (10 nM)-stimulated GH gene transcription by $30 \%$ after $4 \mathrm{~h}$. Transcription of the prolactin (PRL) gene was not suppressed in these cells by IGF-I. Relatively high doses of insulin (200 nM) also suppressed GH gene transcription, but epidermal growth factor and fibroblast growth factor did not change $\mathbf{~ G H}$ mRNA synthesis. The results show that IGF-I exerts a rapid and selective suppression of basal and GHRH-stimulated GH gene transcription. These data indicate a role for IGF-I in negative feedback of GH gene expression and provide evidence for the direct transcriptional regulation of the GH gene by IGF-I in primary rat anterior pituitary cells.
\end{abstract}

\section{Introduction}

Insulinlike growth factor I (IGF-I), ${ }^{1}$ a polypeptide closely related to pro-insulin, is secreted primarily by the liver in response to growth hormone $(\mathrm{GH})(1,2)$. IGF-I is believed to mediate most of the growth-promoting actions of GH (3). Both in vivo and in vitro secretion of pituitary GH have been shown to be suppressed by various IGF-I (somatomedin C) preparations (4-9). We have recently shown that IGF-I suppresses basal GH messenger RNA (mRNA) levels in rat pituitary cells (10) and also inhibits growth hormone-releasing hormone (GHRH)- and triiodothyronine $\left(\mathrm{T}_{3}\right)$-induced $\mathrm{GH}$ mRNA stimulation $(10,11)$.

Address correspondence to Dr. Melmed, Room 1735, Division of Endocrinology, Cedars-Sinai Medical Center, 8700 Beverly Boulevard, Los Angeles, CA 90048. 1986

Received for publication 3 June 1986 and in revised form 18 September

1. Abbreviations used in this paper: EGF, epidermal growth factor; FGF, fibroblast growth factor; GH, growth hormone; GHRH, GH-releasing hormone; IGF-I, insulinlike growth factor I; NC, nitrocellulose; PRL, prolactin; $T_{3}$, triiodothyronine.

J. Clin. Invest

(c) The American Society for Clinical Investigation, Inc.

0021-9738/87/02/0449/04 \$1.00

Volume 79, February 1987, 449-452
This negative feedback of $\mathrm{GH}$ secretion appears to be analogous to the regulation of other pituitary trophic hormones by their respective target hormones. For example, glucocorticoids inhibit the transcription of the proopiomelanocortin gene (12), and thyroid hormone inhibits thyroid-stimulating hormone gene expression (13). It is unclear whether the suppression of $\mathbf{G H}$ gene expression occurs at a transcriptional level, or whether the observed effects of IGF-I could be ascribed to posttranscriptional suppression of GH expression. This study shows that IGF-I directly inhibits the synthesis of new GH mRNA in primary rat pituitary cell cultures.

\section{Methods}

Materials. Recombinant human IGF-I (Thr 59) was purchased from Amgen Biologicals, Thousand Oaks, CA. GHRH (human pancreatic GRF-1-44) was purchased from Peninsula Laboratories (Belmont, CA), while epidermal growth factor (EGF) and fibroblast growth factor (FGF) were purchased from Collaborative Research (Lexington, MA). Semisynthetic purified human insulin was kindly provided by Squibb-Novo, (Princeton, NJ).

Transcription assay. 2-mo-old male Sprague-Dawley rats (220-240 $\mathrm{g}$; Simonsen, Gilroy, CA) were decapitated and their anterior pituitary glands were enzymatically dispersed, as previously described (10). Dispersed pituitary cells were initially plated in serum-containing ( $2.5 \%$ fetal calf serum) medium (HyClone, Logan, UT) and then maintained in serum-free Dulbecco's modified Eagle's medium for $24 \mathrm{~h}$ as described previously $(10,14)$, except that cultures were in $175-\mathrm{cm}^{2}$ flasks. After 1to 24-h treatment of 5-10 $\times 10^{6}$ cells with or without added IGF-I, the cells were scraped from the flasks in sterile phosphate-buffered saline and collected by low-speed centrifugation. The cell pellets were homogenized in $0.32 \mathrm{M}$ sucrose, $3 \mathrm{mM} \mathrm{CaCl}, 2 \mathrm{mM} \mathrm{Mg}$ acetate, $0.1 \mathrm{mM}$ EDTA, $10 \mathrm{mM}$ Tris- $\mathrm{HCl}$, $\mathrm{pH} 8.0,0.1 \%$ Triton $\mathrm{X}$, and $1 \mathrm{mM}$ dithiothreitol (DTT) using 15 strokes of the tight pestle of a Dounce homogenizer (15). The homogenate was diluted with 2 vol of $2 \mathrm{M}$ sucrose, $5 \mathrm{mM} \mathrm{Mg}$ acetate, $0.1 \mathrm{mM}$ EDTA, $10 \mathrm{mM}$ Tris $\mathrm{HCl}, \mathrm{pH} 8.0$, and $1 \mathrm{mM}$ DTT, and then layered over a 10-ml cushion of the $2 \mathrm{M}$ sucrose buffer, and centrifuged at $30,000 \mathrm{~g}$ for $45 \mathrm{~min}$ at $4^{\circ} \mathrm{C}$. The nuclear pellet was resuspended in $100-150 \mu \mathrm{l}$ of $25 \%$ glycerol, $5 \mathrm{mM}$ Mg acetate, $0.1 \mathrm{mM}$ EDTA, $50 \mathrm{mM}$ Tris $\mathrm{HCl}, \mathrm{pH} 8.0$, and $5 \mathrm{mM}$ DTT.

For the transcriptional assay, isolated nuclei $(70 \mu \mathrm{l})$ were incubated with ATP, CTP, and UTP ( $2 \mathrm{mM}$ each), $0.2 \mathrm{mM} \mathrm{GTP}$, and $\left[{ }^{32} \mathrm{P}\right] \mathrm{GTP}$ $(800 \mathrm{Ci} / \mathrm{mmol}, 200 \mu \mathrm{Ci})$ in $0.15 \mathrm{M} \mathrm{KCl}$ and $3 \mathrm{mM} \mathrm{Mg}$ acetate. The reaction $(200 \mu \mathrm{l})$ was continued for $45 \mathrm{~min}$ at $25^{\circ} \mathrm{C}$. After stopping the reaction by $1 \% \mathrm{NaDod} \mathrm{SO}_{4}$ (SDS) in $10 \mathrm{mM}$ EDTA, pH 7.0, $200 \mu \mathrm{l}$ of $3 \mathrm{M}$ sodium acetate, $\mathrm{pH}$ 5.0, was added and mixed. The RNA was extracted by the phenol chloroform method as previously described (14, 16). The ethanol precipitable RNA was dried and dissolved in $100 \mu \mathrm{l}$ of sterile water. An aliquot $(2 \mu \mathrm{l})$ was removed for determining total input $\mathrm{cpm}$. Transcripts containing rGH sequences were quantified by hybridization to nitrocellulose (NC) paper containing immobilized rGH complementary DNA (cDNA) and pBR322 plasmid (each $2 \mu \mathrm{g}$ ) using the dot blot apparatus (Schleicher and Schuell, Inc., Keene, NH). The NC paper, cut into strips, was placed in a polyethylene bag with $1 \mathrm{ml}$ prehybridization buffer consisting of $50 \%$ deionized formamide, $5 \times$ standard saline citrate (SSC), $0.1 \%$ SDS, $5 \times$ Denhardt's solution, denatured salmon 


\begin{tabular}{|c|c|c|c|c|c|}
\hline & \multirow[b]{2}{*}{ Input $\left[{ }^{32} \mathrm{P}\right] \mathrm{RNA}$} & \multicolumn{2}{|c|}{ [ ${ }^{32}$ P]RNA hybridization $(\mathrm{cpm})$} & \multirow{2}{*}{$\begin{array}{l}{\left[{ }^{3} \mathrm{H}\right] \mathrm{cRNA}} \\
\text { hybridized }\end{array}$} & \multirow{2}{*}{$\begin{array}{l}\text { mRNA } \\
\text { synthesized }\end{array}$} \\
\hline & & rGH & pBR322 & & \\
\hline & $\mathrm{cpm} \times 10^{6}$ & & & $\%$ & ppm \\
\hline \multicolumn{6}{|l|}{ Experiment I } \\
\hline Control & 5.0 & 98 & 11 & 31.7 & 54.9 \\
\hline IGF-I (3.25 nM) & 5.0 & 44 & 6 & 33.3 & 22.8 \\
\hline Alpha amanitin $(1 \mu \mathrm{g} / \mathrm{ml})$ & 2.9 & 11 & 9 & 34.2 & 2.0 \\
\hline \multicolumn{6}{|l|}{ Experiment II } \\
\hline Control & 2.5 & 54 & 7 & 29.3 & 64.2 \\
\hline Pituitary poly(A) RNA (100 ng) & 2.5 & 34 & 7 & 18.3 & 59.0 \\
\hline Pituitary poly(A) RNA (500 ng) & 2.5 & 22 & 2 & 11.6 & 68.9 \\
\hline
\end{tabular}

Dispersed pituitary cells $\left(10^{7}\right)$ were tested in serum-free Dulbecco's modified Eagle's medium with or without added IGF-I for $4 \mathrm{~h}$. Cell nuclei were isolated and then incubated in the transcription buffer with $\left.{ }^{32} \mathrm{P}\right] \mathrm{GTP}(200 \mu \mathrm{Ci})$ for $45 \mathrm{~min}$. Alpha amantin was also added in experiment I. New GH mRNA sequences were quantified by hybridization to immobilized $\mathrm{rGH}, \mathrm{cDNA}$, and pBR322 plasmid. Hybridization mixture also contained $\left[{ }^{3} \mathrm{H}\right] \mathrm{GH}$ cRNA $(1,000 \mathrm{cpm})$ to determine the efficiency of hybridization. In experiment II pituitary poly(A) RNA was also added as indicated. After hybridization and washing dots of immobilized DNAs were counted for $20 \mathrm{~min}$.

sperm DNA ( $200 \mu \mathrm{g} / \mathrm{ml}), 5 \mu \mathrm{g} / \mathrm{ml}$ synthetic poly(A) RNA, 2 mM EDTA, and $10 \mathrm{mM}$ Tris $\mathrm{HCl}, \mathrm{pH} 7.0$

After prehybridization for $3 \mathrm{~h}$ at $52^{\circ} \mathrm{C}$, the buffer was replaced with $0.9 \mathrm{ml}$ of fresh prehybridization buffer, and $100 \mu \mathrm{l}$ of the appropriate amount of $\left[{ }^{32} \mathrm{P}\right] \mathrm{RNA}$. GH $\left[{ }^{3} \mathrm{H}\right] \mathrm{complementary} \mathrm{RNA}$ (cRNA) $(1,000 \mathrm{cpm})$ was included in all experiments to determine the efficiency of hybridization and was synthesized as described elsewhere (17) using Hind III digested rGH cDNA insert (18) as template. After hybridization for $3 \mathrm{~d}$ at $52^{\circ} \mathrm{C}$, the $\mathrm{NC}$ paper was washed four times with $100 \mathrm{ml}$ of $2 \times$ $\mathrm{SSC}, 0.1 \% \mathrm{SDS}$ for $10 \mathrm{~min}$ each at room temperature, and three further 30 -min washes were performed at $50^{\circ}, 55^{\circ}$, and $60^{\circ} \mathrm{C}$, respectively, in $0.1 \times$ SSC, $0.1 \%$ SDS. Each dot of immobilized DNA was punched out from the filter strips and the radioactivity determined by liquid scintillation counting ( $10 \mathrm{ml}$ of Aquasol) for $20 \mathrm{~min}$. GH mRNA synthesis is expressed as parts per million and represents [ $\left.{ }^{32} \mathrm{P}\right] \mathrm{RNA}$ bound to rGH cDNA-containing dots minus radioactivity bound to the pBR322 dot, corrected to $100 \%$ hybridization of the added $\mathrm{GH}\left[{ }^{3} \mathrm{H}\right]$ cRNA standard. Nonspecific background binding of the ${ }^{32} \mathrm{P}$-labeled RNA to the DNAfree blank paper was always $<2.5 \mathrm{ppm}$.

Validation of transcriptional assay. During $45 \mathrm{~min}, \sim 15 \%$ of [ $\left.{ }^{32} \mathrm{P}\right]$ GTP was incorporated into nucleic acids, and this was not different in control or IGF-I-treated cells. The nuclear runoff assay performed here is a measure of in vitro elongation of nascent RNA chains. This assay of direct transcriptional activity is dependent on nuclear RNA polymerase II (15). In our experiments, alpha amanitin, an inhibitor of this enzyme, blocked the specific transcription of new GH mRNA. Excess pituitary-derived poly(A) RNA also inhibited the specific hybridization reaction, indicating competitive inhibition for the GH cDNA (Table I). Poly(A) RNA extracted from rat anterior pituitary glands by oligothymidylic acid-cellulose chromatography (19) was added to the hybridization mixtures at the indicated doses. The poly(A) RNA was not pure GH mRNA but nevertheless, $500 \mathrm{ng}$ of poly(A) RNA suppressed hybridization of $\left[{ }^{32} \mathrm{P}\right] \mathrm{GH}$ mRNA by $60 \%$.

\section{Results}

Effect of IGF-I on GH gene transcription. Primary rat pituitary cells grown in serum-free medium were treated with IGF-I (up to $6.5 \mathrm{nM}$ ) or without added IGF-I for $4 \mathrm{~h}$. Cell nuclei from each treatment group were isolated and incubated with $\left[{ }^{32} \mathrm{P}\right] \mathrm{GTP}$ $(200 \mu \mathrm{Ci})$ in the transcription reaction. IGF-I treatment suppressed the transcriptional activity of the GH gene in a dose- responsive manner (Fig. 1). Maximal inhibition ( $58 \pm 2$ vs. $8 \pm 1$ parts per million [ppm]) was seen with $6.5 \mathrm{nM}$ IGF-I, $(n=6$ independent experiments). The transcriptional activity of the PRL gene measured by hybridization against immobilized PRL cDNA (20) was not altered by up to $6.5 \mathrm{nM}$ IGF-I.

The time course of the suppression of new GH mRNA synthesis is shown in Fig. 2. By 4 h, 3.25 nM IGF-I maximally suppressed new GH mRNA synthesis by $70 \%$ (84 \pm 18 vs. $24 \pm 8$ ppm, $n=6, P<0.001$ ). After $24 \mathrm{~h}$, GH gene transcription was still suppressed by $\sim 50 \%$ as compared with control untreated cells.

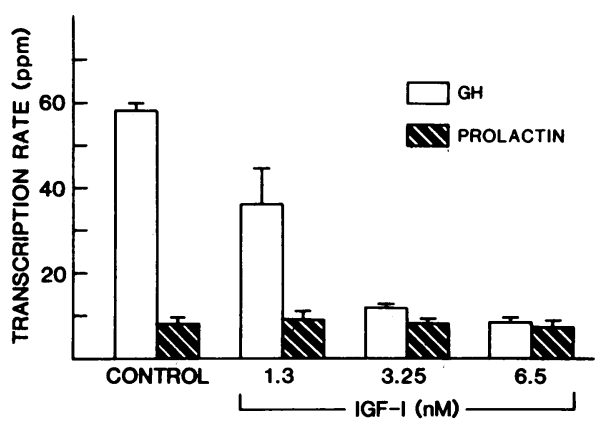

Figure 1. Dose response of IGF-I effect on GH and prolactin gene transcription. Primary cultures of rat anterior pituitary cells were incubated in Dulbecco's modified Eagle's medium containing fetal calf serum (2.5\%). After $3 \mathrm{~d}$, cells were washed and medium replaced with serum-free defined medium with or without added IGF-I for 1-24 h. After the IGF-I treatment, nuclei were isolated and incubated for $\mathbf{4 5}$ $\mathrm{min}$ in an in vitro transcriptional runoff assay with ${ }^{32} \mathrm{P}$-labeled GTP as described. New GH mRNA and prolactin mRNA were measured by hybridization against immobilized GH cDNA and prolactin cDNA (2 $\mu \mathrm{g} / \mathrm{dot})$, respectively. Each hybridization reaction also included a companion immobilized pBR322 DNA blot. GH- and prolactin-specific hybridization are present as parts per million of total input $\left[{ }^{32} \mathrm{P}\right] \mathrm{RNA}$ $\left(\sim 5 \times 10^{6} \mathrm{cpm}\right)$ and the corrections were made for the hybridization efficiency measured by hybridization of ${ }^{3} \mathrm{H}$-labeled cRNA. Bars represent mean and range of duplicate dots from a representative experiment. 


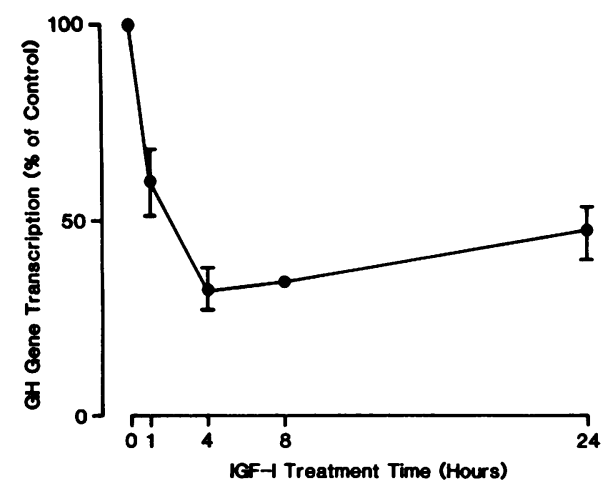

Figure 2. Time course of IGF-I effect on GH gene transcription. After pretreatment with serum-free medium, dispersed monolayer pituitary cells were treated for the times indicated with 3.25 nM IGF-I and nuclei isolated for the transcriptional runoff assay. For each point, the paper was compared with respective controls incubated for the same time with no added IGF-I. Control GH gene transcriptional activity is depicted as $100 \%$. $\left[{ }^{32} \mathrm{P}\right] \mathrm{RNA}$ input into each hybridization was $3.5-10$ $\times 10^{6} \mathrm{cpm}$. Each point represents mean $\pm \mathrm{SD}$ of three to six separate transcription reactions.

Specificity of IGF-I effect on GH gene transcription. GHRH has clearly been shown to stimulate transcription of the GH gene (21); therefore, the effects of IGF-I were tested with GHRH treatment of the cells. As shown in Fig. $3 \mathrm{~A}$, the twofold stimulation of new GH mRNA synthesis induced by GHRH was blocked by IGF-I ( $3.25 \mathrm{nM})$. Other growth factors, including EGF and FGF, did not alter GH transcription (Fig. 3 B). Relatively high doses of insulin ( $200 \mathrm{nM})$ also suppressed the $\mathrm{GH}$ gene transcriptional activity (Fig. $3 \mathrm{C}$ ). This may indicate that insulin is acting via the IGF-I receptor, or alternatively, insulin may specifically inhibit GH gene transcription, in these cells, as we have recently shown for $\mathrm{GH}_{3}$ cell GH gene transcription (22).

\section{Discussion}

Specific receptors for IGF-I, IGF-II, and insulin have been characterized on rat pituitary cells $(23,24)$. The doses of IGF-I used in this study are physiologic, inasmuch as the dissociation constant for IGF-I binding to its receptor sites on rat anterior pi-

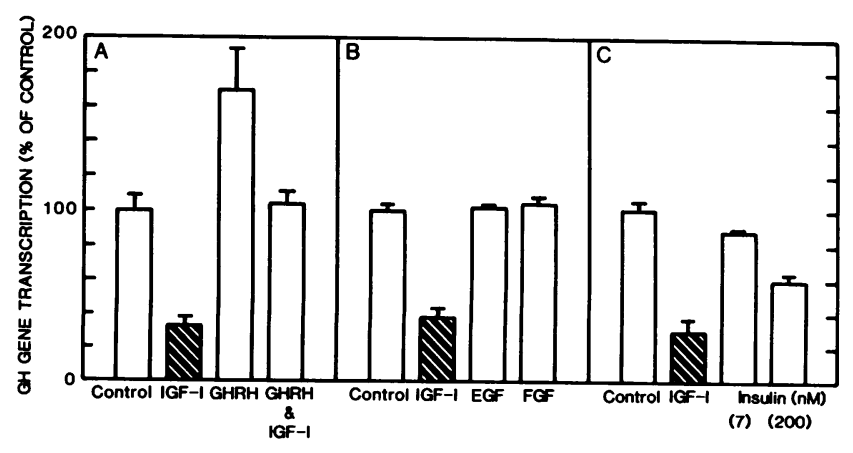

Figure 3. Specificity of IGF-I effect on GH gene transcription. Primary rat pituitary cells were incubated for $4 \mathrm{~h}$ with $(A)$ IGF-I $(3.25 \mathrm{nM})$, GHRH (10 nM), (B) IGF-I (3.25 nM), EGF (50 ng/ml), FGF (50 ng/ $\mathrm{ml}$ ), or $(C)$ insulin ( 7 and $200 \mathrm{nM})$. Nuclei were then isolated and transcriptional runoff assays performed. Each bar represents mean \pm range of duplicate dots. tuitary cells is $\sim 1 \mathrm{nM}$. The suppression of $\mathrm{GH}$ by various somatomedin $\mathrm{C}$ preparations has been shown to occur directly at the level of GH mRNA (10) and GH secretion $(4,5,8,9)$, and also to occur in vivo after intracerebroventricular insertion $(6$, 7). Although the anterior pituitary contains relatively abundant binding sites for IGF-II $(23,24)$, IGF-II appears to be less potent than IGF-I as an inhibitor of GHRH-stimulated GH secretion (5).

IGF-I did not alter the total incorporation of $\left.{ }^{32} \mathrm{P}\right] \mathrm{GTP}$ into RNA in the nuclear transcription assay. This indicates that IGF-I did not generally suppress the total RNA synthesis in these experiments. This is in agreement with our previous observations that total pituitary RNA levels were not altered in rats bearing GH-secreting tumors with resultant elevated IGF-I levels (25). These experiments demonstrate for the first time, that the IGF-I (Thr-59) analogue (26) with similar competitive binding and bioactive behavior to purified somatomedin C (27), a naturally occurring polypeptide, is able to suppress transcription of the pituitary GH gene. Heretofore, the transcriptional regulation of $\mathrm{GH}$ has been shown to be primarily stimulatory by $\mathrm{T}_{3}$, hydrocortisone, and GHRH (28-31). Although somatostatin inhibits the release of $\mathrm{GH}$, this hypothalamic hormone has not been shown to regulate GH gene expression (32). Insulin has also been shown to suppress GH secretion, mRNA levels, and GH gene transcription, but the dose response and time course for these observations clearly differed from the effects elicited by IGF-I $(10,14,22,33)$.

The previously observed inhibition of pituitary GH mRNA levels induced by IGF-I (10) may have been due to other posttranscriptional events, including an increase in GH mRNA degradation, processing, or transport (34). The half-life of $\mathrm{GH}$ mRNA in GH cells has been reported to range from 40 to $56 \mathrm{~h}$ (30), while in other studies a shorter half-life has been reported (31). We have previously shown that IGF-I inhibits the GH mRNA levels in normal rat pituitary cells after $48 \mathrm{~h}$, and also suppresses GH secretion after only $4 \mathrm{~h}(10)$. This would suggest that IGF-I may also act at a posttranscriptional level to inhibit GH secretion. Nevertheless, the data shown here indicate that IGF-I directly and selectively inhibits the synthesis of nascent GH mRNA in normal rat pituitary cells without altering PRL mRNA synthesis.

These observations indicate the presence of a negative feedback loop in the regulation of pituitary GH gene transcription. In addition to GHRH, $T_{3}$, and hydrocortisone, therefore, IGF-I participates in the balance of GH gene regulation by inhibiting GH gene transcription. This observation may explain the high GH levels seen in starvation and protein-calorie malnutrition where IGF-I levels are suppressed (35). These findings may also provide the molecular mechanism for the regulation of human GH secretion (9) and GH mRNA levels (36) by IGFI. The physiologic significance of these reciprocal changes remain to be determined.

\section{Acknowledgments}

The authors acknowledge the outstanding technical assistance of Helen Kado and Susan Slanina, and the secretarial assistance of Grace Labrado. The rat GH and PRL cDNA probes were kindly provided by Drs. John Baxter and Norman Eberhardt, University of California, San Francisco, CA.

This work was supported by National Institutes of Health grant AM33802 from the National Institute of Arthritis, Diabetes, Digestive and Kidney Diseases. 


\section{References}

1. Clemmons, D. R., and J. J. Van Wyk. 1984. Factors controlling blood concentration of somatomedin-C. Clin. Endocrinol. Metab. 13: 113-143.

2. Czech, M. P. 1982. Structural and functional homologies in the receptors for insulin and the insulin-like growth factors. Cell. 31:8-10.

3. Salmon, W. D., and W. H. Daughaday. 1957. A hormonally controlled serum factor which stimulates sulfate incorporation by cartilage in vitro. J. Lab. Clin. Med. 49:825-836.

4. Berelowitz, M., M. Szabo, L. A. Frohman, S. Firestone, L. Chu, and R. L. Hintz. 1982. Somatomedin-C mediates growth hormone negative feedback by effects on both the hypothalamus and the pituitary. Science (Wash. DC). 212:1279-1281.

5. Brazeau, P., R. Guillemin, N. Ling, J. J. Van Wyk, and R. Humbell. 1982. Inhibition by somatomedins of growth hormone secretion stimulated by hypothalamic growth hormone releasing factor (somatocrinin GRF) on the synthetic peptide hpGRF. C.R. Acad. Sci. Paris. 295:651654 .

6. Tannenbaum, G. S., H. J. Guyda, and B.I. Posner. 1983. Insulinlike growth factors: a role in growth hormone negative feedback and body weight regulation via brain. Science (Wash. DC). 220:77-79.

7. Abe, H., M. E. Molitch, J. J. Van Wyk, and L. E. Underwood. 1983. Human growth hormone and somatomedin $C$ suppress the spontaneous release of growth hormone in unanesthetized rats. Endocrinology. 113:1319-1324.

8. Goodyer, C. G., L. De Stephano, H. J. Guyda, and B. I. Posner. 1984. Effects of insulin-like growth factor on adult male rat pituitary function in tissue culture. Endocrinology. 115:1568-1576.

9. Ceda, G. P., A. R. Hoffman, G. D. Silverberg, D. M. Wilson, and R. G. Rosenfeld. 1985. Relation of GH release from cultured human pituitary adenomas by somatomedins and insulin. J. Clin. Endocrinol. Metab. 60:1204-1209.

10. Yamashita, S., and S. Melmed. 1986. Insulin-like growth factor I action on rat anterior pituitary cells: suppression of growth hormone secretion and messenger ribonucleic acid levels. Endocrinology. 118:176182.

11. Melmed, S., and S. Yamashita. 1986. Insulin-like growth factor I action on hypothyroid rat pituitary cells: suppression of triiodothyronine-induced GH secretion and mRNA levels. Endocrinology. 118:14831490.

12. Eberwine, J. H., and J. L. Roberts. 1982. Glucocorticoid regulation of pro-opiomelanocortin gene transcription in the rat pituitary. J. Biol. Chem. 259:2166-2170.

13. Shupnik, M. A., W. W. Chin, J. F. Habener, and E. C. Ridgway. 1985. Transcriptional regulation of the thyrotropin subunit genes by thyroid hormone. J. Biol. Chem. 260:2900-2905.

14. Yamashita, S., and S. Melmed. 1986. Effects of insulin on rat anterior pituitary cells: inhibition of growth hormone secretion and mRNA levels. Diabetes. 35:440-447.

15. Marluff, W. F., and R. C. C. Huang. 1984. Transcription of RNA in isolated nuclei. In The Transcription and Translation (B. D. Haines and S. J. Higgens, editors). IRI Press, Oxford. 88-129.

16. Feramisco, J. R., J. E. Smart, K. Burridge, D. M. Helfman, and G. P. Thomas. 1982. Co-existence of viculin and a viculin-like protein of higher M.W. in a smooth muscle. J. Biol. Chem. 257:11024-11033.

17. McKnight, G. S., and R. D. Palmiter. 1979. Transcriptional regulation of the ovalbumin and conalbumin genes by steroid hormones in chick oviduct. J. Biol. Chem. 254:9050-9058.

18. Seeburg, P. H., J. Shine, J. A. Martial, J. D. Baxter, and H. M.
Goodman. 1977. Nucleotide sequence and amplification in bacteria of structural gene for rat growth hormone. Nature (Lond.). 270:486-494.

19. Aviv, H., and P. Leder. 1972. Purification of biologically active globin mRNA by chromatography on oligothymidylic acid-cellulose. Proc. Natl. Acad. Sci. USA. 69:1408-1412.

20. Cooke, N. E., D. Coit, R. Weiner, J. D. Baxter, and J. A. Martial. 1980. Structure of cloned DNA complementary to rat PRL messenger RNA. J. Biol. Chem. 255:6502-6510.

21. Barinaga, M., G. Yamamoto, C. Rivier, W. Vale, R. Evans, and M. G. Rosenfeld. 1983. Transcriptional regulation of growth hormone gene expression by growth hormone releasing factor. Nature (Lond.). 306:84-85

22. Yamashita, S., and S. Melmed. 1986. Insulin regulation of growth hormone gene transcription. J. Clin. Invest. 78:1008-1014.

23. Goodyer, C. G., L. DeStephano, W. H. Lei, H. J. Guyda, and B. I. Posner. 1984. Characterization of insulin-like growth factor receptors in rat anterior pituitary hypothalmus and brain. Endocrinology. 114: $1187-1195$.

24. Rosenfeld, R. G., G. Ceda, D. M. Wilson, L. A. Dollar, and A. R. Hoffman. 1985. Insulin and insulin-like growth factor (somatomedin) receptors on cloned rat pituitary tumor cells. Endocrinology. 114:1571-1575.

25. Yamashita, S., S. Slanina, H. Kado, and S. Melmed. 1986. Autoregulation of pituitary growth hormone mRNA levels in rats bearing transplantable mammosomatotrophic pituitary tumors. Endocrinology. 118:915-918.

26. Peters, M. A., E. P. Lau, D. L. Snitman, J. J. Van Wyk, L. E. Underwood, W. E. Russell, and M. E. Svoboda. 1985. Expression of a biologically active analogue of somatomedin-C/insulin-like growth factor I. Gene. 35:83-89.

27. Schalch, D., D. Reisman, C. Emler, P. Humbel, C. H. Li, M. A. Peters, and E. P. Lau. 1984. Insulin-growth factor I/somatomedin C: comparison of natural, solid phase synthetic and recombinant DNA analogue peptides in two radioligand assay. Endocrinology. 115:2490-2492.

28. Evans, R. M., N. C. Birnberg, and M. G. Rosenfeld. 1982. Glucocorticoid and thyroid hormones transcriptionally regulate growth hormone gene expression. Proc. Natl. Acad. Sci. USA. 78:7659-7663.

29. Spindler, S. R., S. H. Mellon, and J. D. Baxter. 1982. Growth hormone gene transcription is regulated by thyroid and glucocorticoid hormones in cultured rat pituitary tumor cells. J. Biol. Chem. 257:1162711632.

30. Yaffe, B. M., and H. H. Samuels. 1984. Hormonal regulation of the growth hormone gene. J. Biol. Chem. 259:6284-6291.

31. Diamond, D. J., and H. M. Goodman. 1985. Regulation of growth hormone messenger RNA synthesis by dexamethasone and triiodothyronine. Transcriptional rates and mRNA stability changes in pituitary tumor cells. J. Mol. Biol. 181:41-62.

32. Simard, J., F. Gossard, C. Kreis, and F. Labrie. 1985. Multiple control of GH mRNA levels and GH synthesis in cultured rat anterior pituitary cells. Annu. Meet. Endocrine Soc., 67th, Baltimore. 479. (Abstr.)

33. Melmed, S., L. Neilson, and S. Slanina. 1985. Insulin suppresses rat growth hormone mRNA levels in rat pituitary tumor cells. Diabetes. 34:408-412.

34. Goldfine, I. D., F. Purello, G. A. Clauson, and R. Vignen. 1982. Insulin binding sites on the nuclear envelope: potential relationship to mRNA metabolism. J. Cell. Biochem. 20:29-39.

35. Phillips, L. S. 1986. Nutrition, somatomedins and the brain. Metab. Clin. Exp. 35:78-87.

36. Yamashita, S., M. Weiss, and S. Melmed. 1986. Insulin-like growth factor I regulates GH secretion and mRNA levels in human pituitary tumor cells. J. Clin. Endocrinol. Metab. 63:730-736. 